\title{
STRUKTUR KALIMAT KAUSATIF DALAM BAHASA ACEH SINGKIL: ANALISIS TEORI X-BAR
}

\section{Causative Sentences Structure on Aceh Singkil Language: Analysis X-BAR Theory}

\author{
Syafriani Tio Sari dan Mulyadi \\ Universitas Sumatra Utara \\ tanggal naskah masuk 10 September 2018 \\ tanggal akhir penyuntingan 29 November 2018
}

\begin{abstract}
This study deals with the analysis of sentences causative on Aceh Singkil language. Causative sentences on Aceh Singkil language is a sentence involving two components or cause and effect cycle. Causative contructions has tree types of causatives: morphologic, syntactic dan semantic. The research method is simak. Data were analyzed and presented with formal and informal methods. This paper analyzes the causative sentences structure using X-bar theory. This result showed that causative sentences formed by spesifier, inflection, and verb phrase.
\end{abstract}

Keywords: Causative Constructions, Aceh Singkil Language, X-Bar Theory

\begin{abstract}
Abstrak
Penelitian ini adalah analisis kalimat kausatif dalam bahasa Aceh Singkil. Kalimat kausatif bahasa Aceh Singkil merupakan kalimat yang melibatkan dua komponen atau kejadian sebab akibat. Di dalam konstruksi ini dikenal juga dengan konstruksi morfologis, sintaktis dan semantis. Penelitian ini menggunakan metode simak. Kemudian data dianalisis dan disajikan dengan metode formal dan informal. Tulisan ini menganalisis struktur kalimat kausatif tersebut menggunakan teori X-Bar. Hasil penelitian menunjukkan bahwa struktur dasar kalimat kausatif dibentuk dari spesifier, infleksi, dan frasa verba.
\end{abstract}

Kata-kata Kunci: Konstruksi Kausatif, Bahasa Aceh Singkil, Teori X-Bar

\section{PENDAHULUAN}

Konsep tentang konstruksi kausatif diungkapkan oleh Goddard yang menyatakan bahwa konstruksi kausatif merupakan satu ungkapan yang di dalamnya mengandung sebuah peristiwa yang disebabkan oleh perbuatan seseorang atau karena sesuatu terjadi (Goddard, 1998). Secara umum, konstruksi kausatif menggambarkan mikro atau peristiwa yang terdiri atas (1) peristiwa penyebab (causee) yang menyebabkan suatu peristiwa terjadi (causing event) dan (2) peristiwa yang terjadi atau akibat yang timbul (caused) yang disebabkan oleh tindakan tersebab (causee) (Shibatani, 1976; Comrie, 1981).

Tipe konstruksi kausatif Bahasa Indonesia, terbagi atas monoklausa dan biklausa. Ciri kausatif monoklausa ialah bahwa argumen-argumen dari predikat kausatif menyandang fungsi gramatikal yang berbeda. Dalam struktur kausatif monoklausa verba sematan berpindah ke [SpES Fp] dan kemudian berinkorporasi ke dalam predikat kausatif matriks. Kausatif biklausa dicirikan oleh adanya dua fungsi gramatikal ganda dalam predikat kausatif, misalnya, adanya dua objek langsung atau dua objek tak langsung. Dalam struktur biklausa verba sematan berpindah ke [SPES FP] dan berinkorporasi ke dalam predikat kausatif matriks serta meninggalkan argumen internalnya di bawah [SPES FP] (Mulyadi, 2004, hlm.139). 
Konstruksi kausatif terbagi atas konstruksi morfologis, konstruksi sintaktis atau perifrastis dan konstruksi semantis atau leksikal (Payne, 1997). Kausatif Perifrastis di mana bentuk-bentuk verba beragam digunakan untuk mengungkapkan apa yang secara umum diungkapkan oleh sebuah verba dalam konjungsi dengan afiks. Kausatif Morfologi yang verbanya ditunjukkan oleh afiks-sufiks. Kausatif Leksikal yang dinyatakan oleh sebuah leksikon tanpa melalui proses produktif apa pun. Leksikon tersebut secara mandiri dapat mengekspresikan hubungan sebabakibat sekaligus.

Pembentukan kalimat kausatif biasanya ditandai dengan adanya kata sebab atau karena dan akibat. Setiap bahasa memiliki cara tersendiri untuk menyatakan konstruksi kausatif. Salah satu cara yang umum ialah dengan menggunakan kalimat kompleks, yaitu kalimat yang terdiri atas satu klausa yang menyebabkan sebab dan satu klausa lain untuk menyatakan akibat. Kedua klausa ini dihubungkan dengan menggunakan konjungsi yang bermakna kausatif (Mayani, 2005, hlm. 237). Karena menggunakan kalimat yang kompleks ada baiknya jika kalimat tersebut ditelaah menggunakan pendekatan sintaksis generatif dengan teori X-Bar.

Bahasa Aceh Singkil sebagai salah satu bahasa daerah di Indonesia. Bahasa Aceh Singkil ini merupakan percampuran dari beberapa bahasa seperti bahasa Melayu Pesisir, bahasa Batak, dan bahasa Padang. Hal inilah yang membuat penulis tertarik untuk meneliti bahasa tersebut. Kausatif berkaitan dengan perbuatan (verba) yang menyebabkan sesuatu keadaan atau kejadian. (Kridalaksana, 2009). Contohnya dalam kalimat kausatif analitik tersebut:

\section{Umak mambuek adik tidu \\ Ibu Kaus adik Akt-tidur \\ "Ibu membuat adik jadi tidur"}

\section{Urang tu pai}

Orang Def pergi

"Orang itu pergi"

Contoh dalam diagram pohon teori X-bar

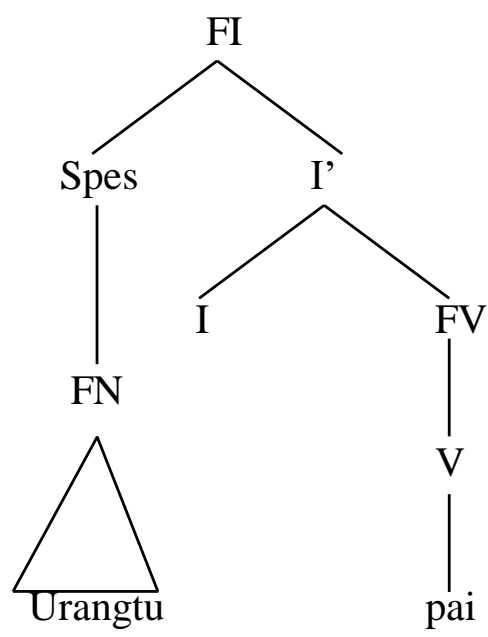

Teori X-Bar

Teori X-bar menjelaskan struktur umum frasa yang direpresentasikan pada skema X-bar. Noam Chomsky merupakan orang pertama yang mengemukakan bahwa frasa mempunyai struktur yang sama dan harus dikaji secara eksplisit. Chomsky belajar dari Zellig Harris yang merupakan penggasas dari teori X-bar. Dalam kaidah ini terdapat dua tipe kategori: pertama, kategori leksikal seperti verba, nomina, adjektiva, dan preposisi; dan kedua, kategori frasa seperti frasa verba, frasa nomina, frasa adjektiva, dan frasa preposisi. Pada masa itu belum disinggung adanya sebuah kategori yang lebih besar dari kategori leksikal, tetapi lebih kecil dari kategori frasa, seperti diantara nomina dan frasa nomina atau diantara verba dan frasa verba. Faktanya, melalui sejumlah tes sintaksis seperti subtitusi, koordinasi, atau pronominalisasi terbukti adanya kategori tersebut. Inilah yang disebut kategori antara (intermediate category) dan menjadi dasar munculnya teori X-bar (Mulyadi, 2010, hlm.3; diadaptasi dari Haegeman, 1994).

Perlu diketahui bahwa dalam teori Penguasaan dan Pengikatan struktur dasar sebuah konstruksi kausatif terdiri atas kalimat matriks dan kalimat sematan. 
Kalimat sematan adalah konstituen yang didominasi oleh frasa infleksional (FI), terdiri atas FN subjek (pesebab) plus satu FN objek berupa pasien sesuai dengan valensi verba sematan. Kalimat matriks adalah konstituen yang berada di atas posisi [SPES, FP] atau di atas K', terdiri atas FN subjek (penyebab) dan verba kausatif. Posisi $P$ adalah untuk pemerlengkap seperti that atau fordalam bahasa Inggris, posisi [SPES, FP) untuk frase wh-dalam bahasa Inggris. Diasumsikan bahwa predikat kausatif menginkorporasi verba yang lebih rendah, $\mathrm{V}$, untuk menghasilkan sebuah predikat kompleks. Struktur dasar sebuah konstruksi kausatif dapat digambarkan pada diagram berikut (Mulyadi, 2004, hlm.137).

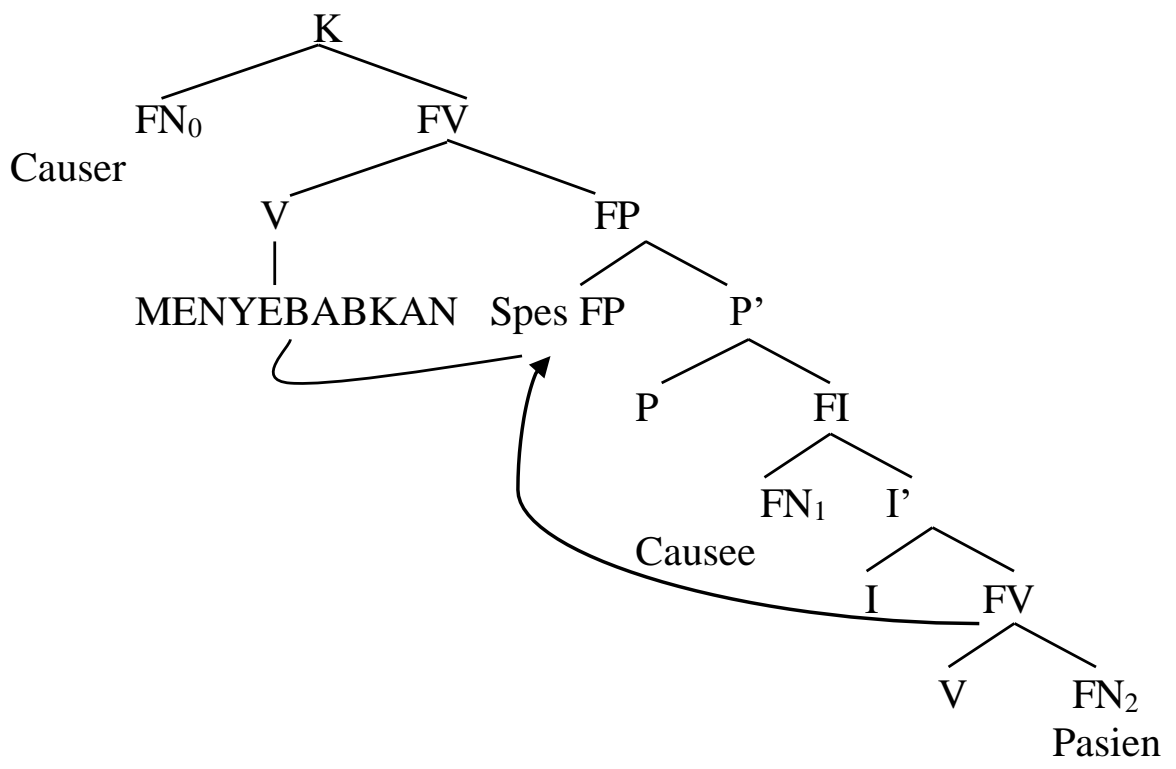

Konstituen FV yang didominasi oleh I' dapat berpindah ke posisi [SPES, FP] dan meninggalkan jejak pada posisinya yang lama. Hal ini menaikkan seluruh FV sehingga tidak lagi berada di bawah FI. Dari posisi ini, inti verba dari FV yang lebih rendah kemudian berinkorporasi ke dalam predikat MENYEBABKAN. Sementara itu, FN pesebab (subjek yang lebih rendah) diperlakukan sebagai keterangan atau oblik yang dimarkahi sebagai objek kedua. Teori ini digunakan untuk mendeskripsikan struktur yang membangun konstruksi kausatif bahasa Aceh Singkil.

\section{LANDASAN TEORI}

Mulyadi (2004) dalam artikel "Konstruksi Kausatif dalam Bahasa Indonesia" membahas (1) perilaku verba dalam membentuk konstruksi kausatif bI,
(2) tipe-tipe konstruksi kausatif bI, dan (3) struktur konstruksi kausatif bI. Data dikaji dengan metode distribusional dengan alat penentu berupa struktur argumen verba. Penelitian ini menggunakan pendekatan tipologis dan sintaksis. Hasil penelitian ini menunjukkan bahwa dalam pembentukan konstruksi kausatif, verba intransitif berubah menjadi transitif, sedangkan verba transitif dan ditransitif tidak mengalami perubahan. Mayani (2005) dalam artikel "Konstruksi Kausatif Bahasa Madura" membahas konstruksi kausatif berdasarkan parameter morfosintaksis dan semantis bM. Sistem kerja yang digunakan merujuk pada penggunaan konjungsi yang terdapat dalam kalimat kompleks. Hasil penelitian menunjukkan bahwa semua tipe pembagian kausatif terdapat pada BM. Verba Ngabay [N+gabay] 'membuat' dan nyoro $[\mathrm{N}+$ soro $]$ 'menyuruh' adalah verba kausatif yang digunakan dalam kausatif 
analitik BM. Afiks yang digunakan sebagai pemarkah kausatif morfologis BM adalah $\{m a-\}, \quad\{-a g h i\}, \quad\{m a--a g h i\}$, $\{m a+\mathrm{N}--a g h i\}$, dan $\{p a-\}$. Selanjutnya, konstruksi kausatif leksikal BM sama dengan struktur logis konstruksi kausatif morfologis, yaitu [do (X)] CAUSE [BECOME predicate (Y)]. Hadi (2007) dalam artikel "Konstruksi Kausatif Bahasa Serawai" mengenai konstruksi kausatif bS berdasarkan parameter morfosintaksis dan parameter semantis. Sistem kerja yang digunakan juga merujuk pada penggunaan konjungsi (sejalan dengan Mayani, 2005). Hasil penelitian menunjukkan bahwa konstruksi kausatif bS dapat dilakukan dengan beberapa cara, yaitu (1) menggunakan kalimat kompleks - dua klausa digabungkan dengan menggunakan konjungsi kernau/ sebap,

menggunakan kausatif analitik - dengan penanda verbanya nganuka 'membuat', njadika 'membuat jadi', dan ngajung 'menyuruh', (3) menggunakan kausatif morfologis - dengan menambahkan afiks $n g-k a$ (dengan alomorf-alomorfnya), $n g-i$ (dengan alomorf-alomorfnya) $-k a$ dan $-i$, dan (4) memilih verba kausatif leksikal tertentu yang sudah bermakna kausatif. Dalam parameter semantis dijelaskan kesinoniman verba kausatif dalam bS. Analisis itu diawali dengan mendistribusikan verba kausatif ke dalam kalimat, lalu mensubstitusikannya ke dalam konstruksi yang lebih luas, kemudian menunjukkan batas-batas kemampuannya dalam bersubstitusi. Penelitian ini dijadikan referensi dalam memperkaya konsepsi peneliti dalam memerikan kausatif bahasa nusantara.

\section{METODE PENELITIAN}

Data yang digunakan dalam tulisan ini merupakan data lisan. Data lisan sebagai data primer diperoleh dari informan Bahasa Aceh Singkil, yang dipilih berdasarkan beberapa kriteria, diantaranya:
1. Penutur asli bahasa Aceh Singkil

2. Informan telah mencapai cukup umur dan tidak pikun

3. Memiliki alat ucap normal

4. Memiliki pengetahuan yang cukup tentang Bahasa Aceh Singkil, dan

5. Bersedia menjadi informan dan mempunyai cukup waktu.

Penelitian ini dikumpulkan dengan menerapkan metode simak. Disebut "metode simak" atau "penyimakan" karena memang berupa penyimakan: dilakukan dengan meyimak penggunaan bahasa (Sudaryanto, 2015).

Data yang diperoleh kemudian dianalisis dengan teori X-bar untuk melihat struktur setiap jenis kalimat kausatif. Data yang disajikan dalam kajian ini menggunakan metode formal dan informal. Metode formal dapat disajikan dalam bentuk diagram dan informal dapat disajikan dengan kata-kata biasa.

\section{PEMBAHASAN \\ Kalimat Kausatif dalam Bahasa Aceh Singkil}

\section{Kausatif Morfologis}

Afiks yang merupakan pemarkah kausatif dalam bahasa Aceh Singkil salah satunya adalah afiks ma.

3. Karosi tu jatuh

Kursi Def jatuh

"Kursi itu jatuh"

\section{3a. Ayah manjatuhkan karosi tu}

Ayah Kaus- jatuh -Kauskursi Def

"Ayah menjatuhkan kursi itu"

\section{Umak mambali susu \\ Ibu Akt-beli susu \\ "Ibu membeli susu"}

4a. Umak mambali susu dakek adik

Ibu Akt-beli susu untuk adik

"Ibu membeli susu untuk adik" 
(3)

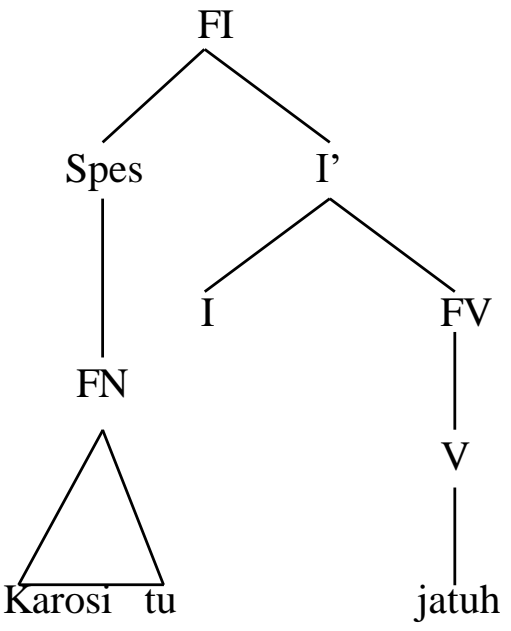

(3a)

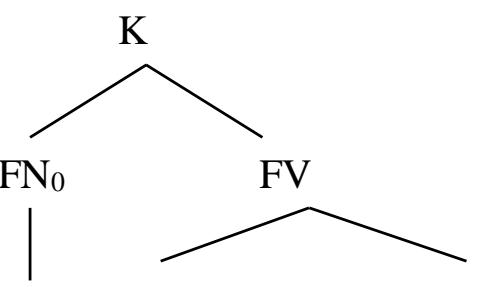

Ayah

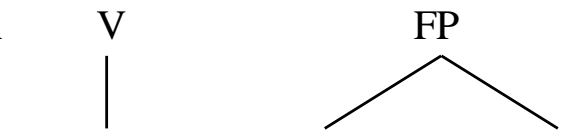

menjatuhkan $_{\mathrm{i}} \quad$ Spes FP
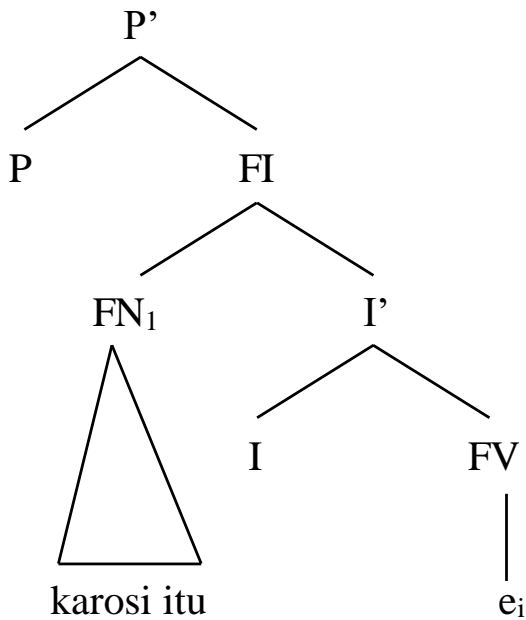

(4)

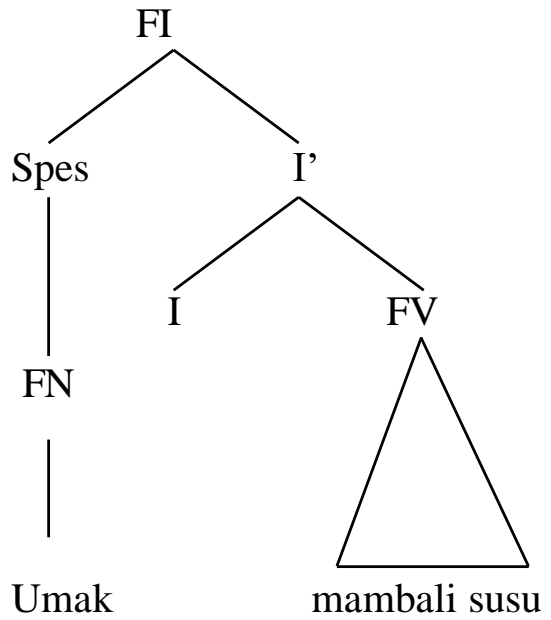


Data (3) sebagai kontruksi dasar, afiks kausatif direpresentasikan sebagai sebuah verba yang memerlukan komplemen kausal, Itu sebabnya, dalam struktur derivasi, verbanya berpindah keposisi [SPES, FP]. Pada (3a), verba jatuh yang semula didominasi oleh sebuahFV di bawah simpai FI berpindah ke posisi Spes FP dan meninggalkan jejak pada posisinya yang lama. Verba tersebut kemudian diinkorporasi oleh predikat kausatif matriks.

(5)

MENYEBABKAN Spes FP
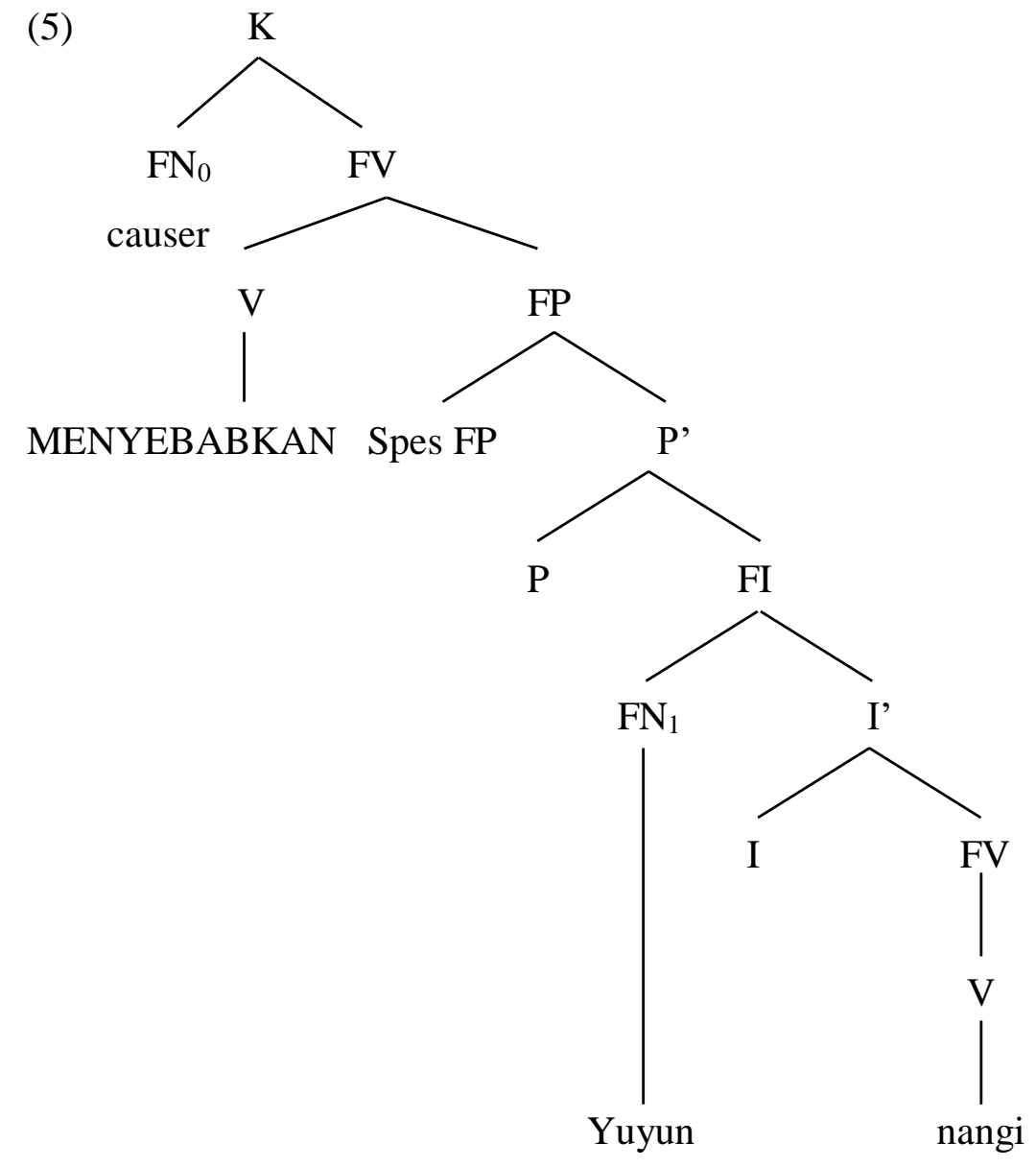

\section{Kausatif Sintaktis atau Perifrastis}

mambuek 'membuat' dan manyuruh 'menyuruh" adalah verba kausatif yang digunakan dalam konstruksi kausatif sintaktis bahasa Aceh Singkil.

5. Yuyun nangi

Yuyun Akt-tangis

"Yuyun menangis"

5a. Zul mambuek Yuyun nangi

Zul Kaus Yuyun Akt-tangis

"Zul membuat Yuyun menangis" 
(5a)

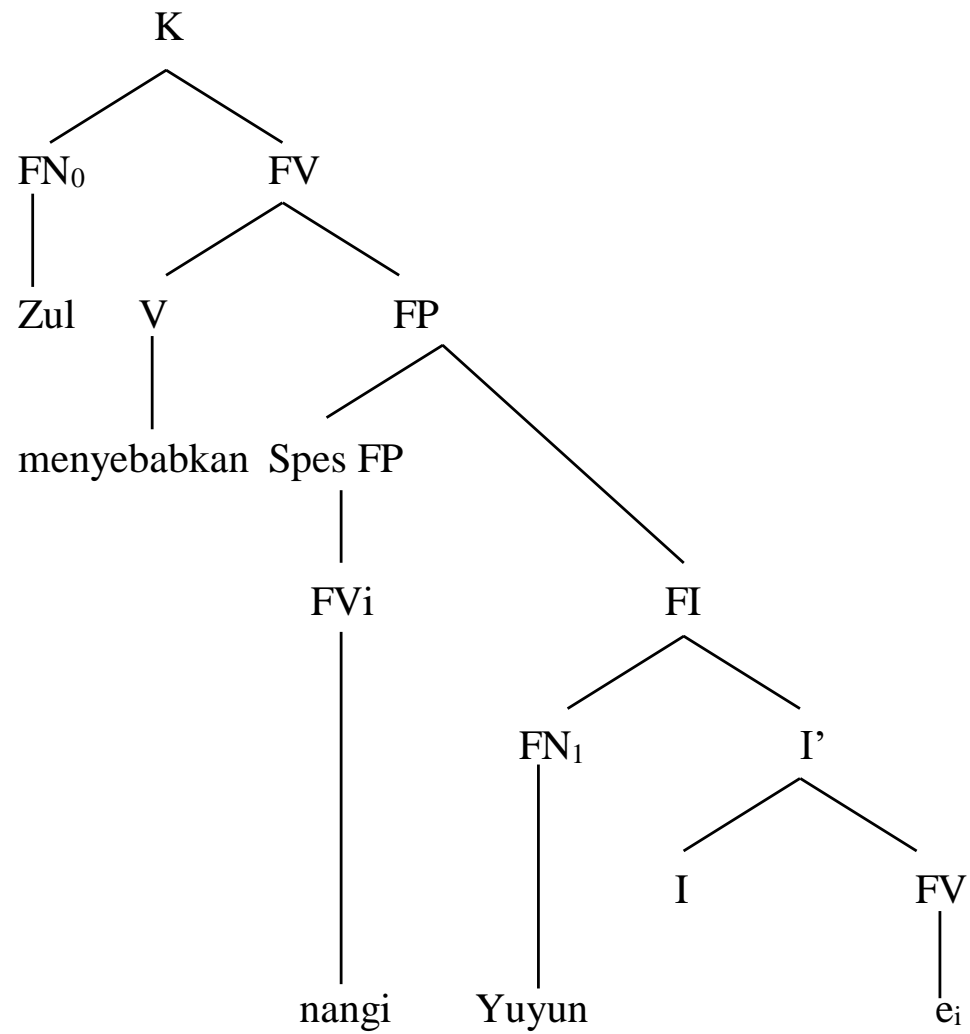

6. Adiktidu

Adik Akt-tidur

"adik tidur"

6a.Umak mambuek adik tidu

Ibu Kaus adik Akt-tidur

"Ibu membuat adik jadi tidur"

(6)

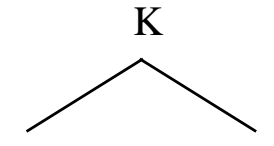

$\mathrm{FN}_{0} \quad \mathrm{FV}$

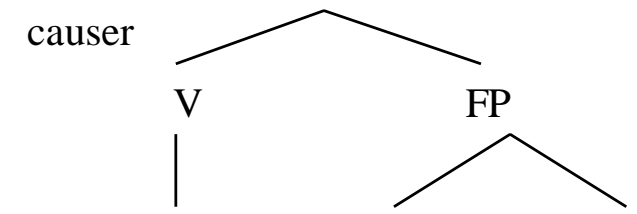

MENYEBABKAN Spes FP
7. Ambo mambaiutang

P $1 \mathrm{t}$ Akt-bayar utang

"saya membayar utang"

7a.Uda manyuruh ambo mambaiutang

Abang Kaus Plt Akt-bayar utang

"abang menyuruh saya membayar utang"

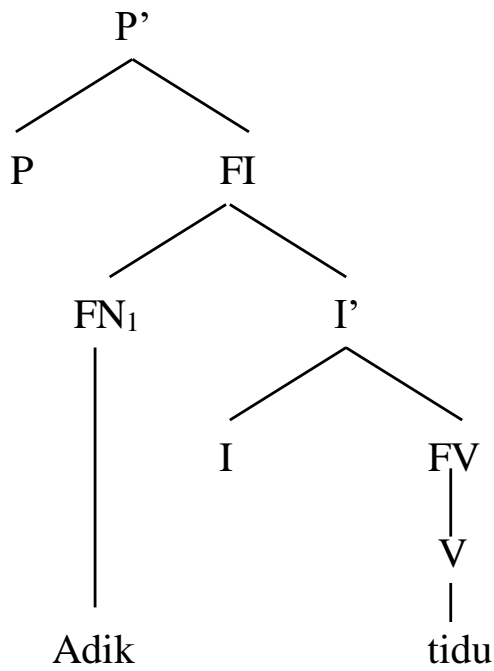



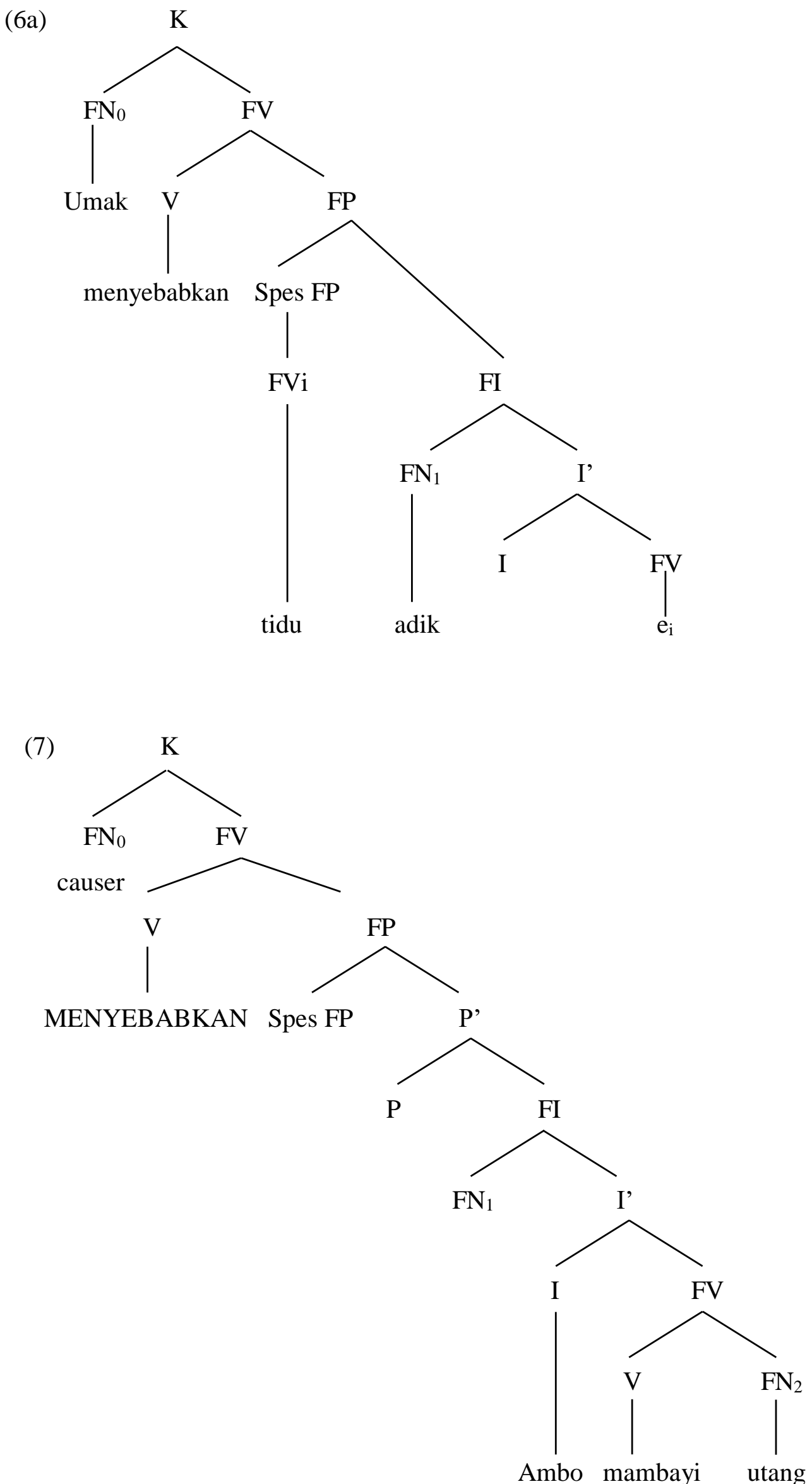
(7a)

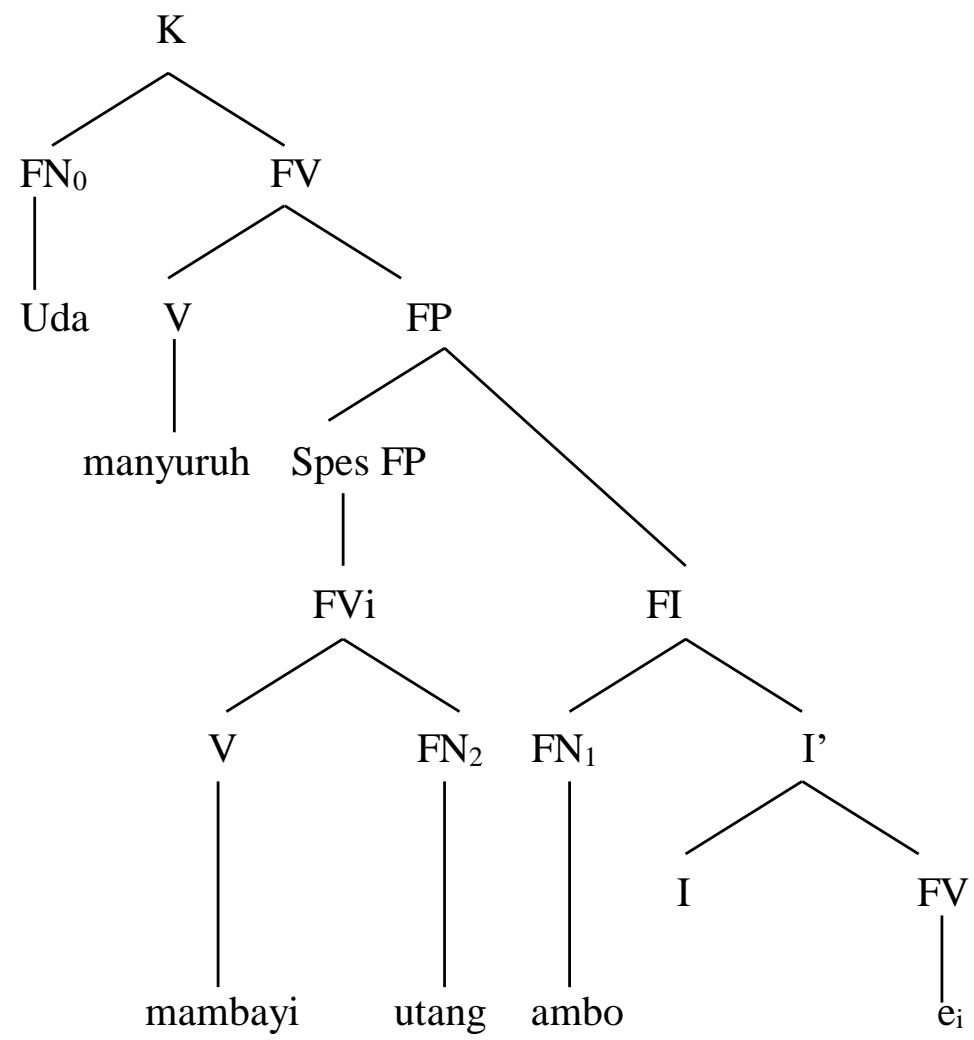

Dari data di atas terlihat bahwa perubahan konstruksi nonkausatif, baik konstruksi dengan verba dasar intransitif maupun dengan verba transitif, pada kalimat (5), (6), (7) menjadi konstruksi kausatif (5a), (6a), dan (7a) mengharuskan kehadiran verba kausatif mambuek dan manyuruh. Dampak dari penambahan verba kausatif ini adalah adanya penambahan satu argumen yang berfungsi sebagai penyebab. Kehadiran verba mambuek pada kalimat (5a) menuntut kehadiran Zul sebagai penyebab untuk melakukan sesuatu dan menyebabkan Yuyun nangi. Sama halnya dengan (6a) menuntut kehadiran umak sebagai penyebabuntuk melakukan sesuatu dan menyebabkan adik tidu. Kalimat (7a) verba kausatif manyuruhmenyebabkan uda melakukan sesuatu terhadap ambo sehingga ambo mambai utang.

\section{Kausatif Semantis atau Leksikal}

Seperti halnya kausatif morfologis, situasi-situasi mikro dalam konstruksi kausatiif semantis/leksikal juga dituangkan 
(8)
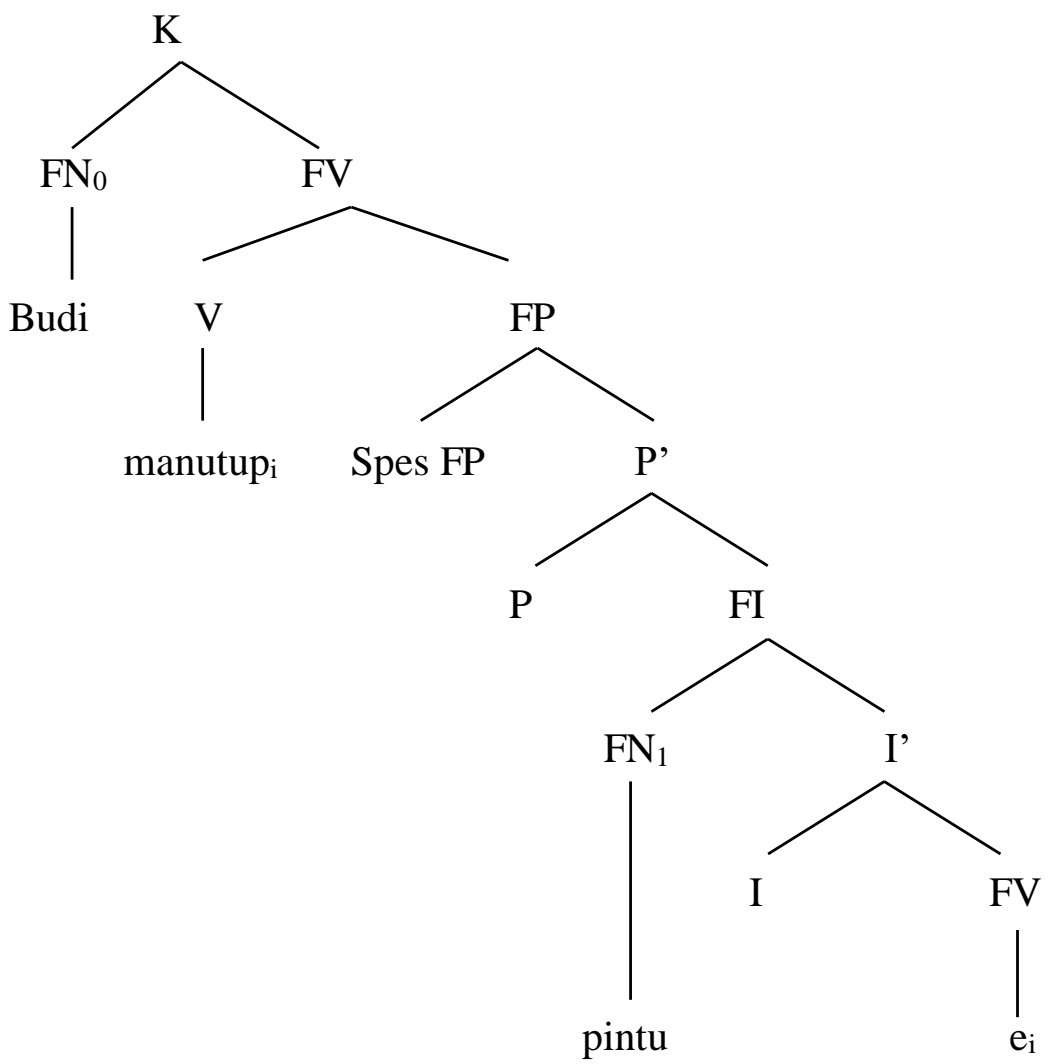

(9)

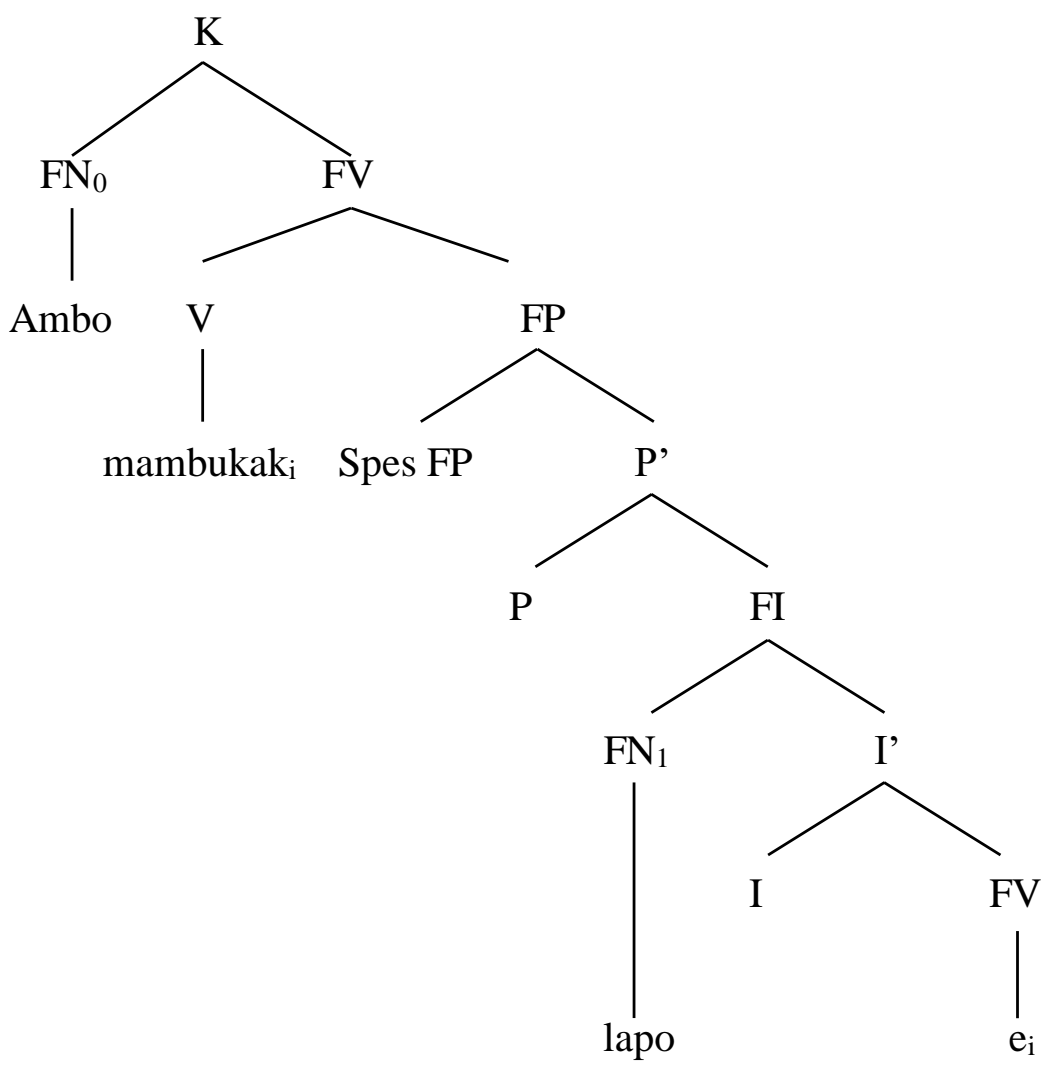


$(10$

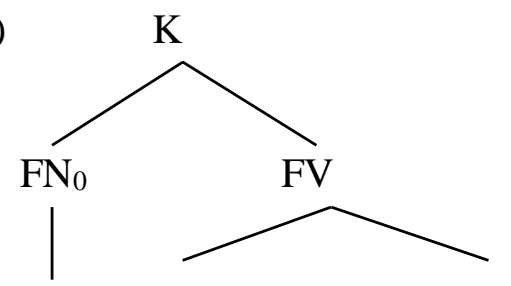

Angku

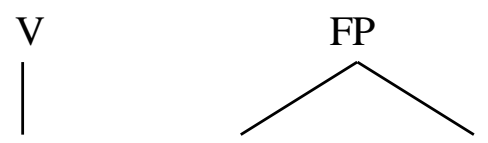

mambunuh $_{i}$ Spes FP
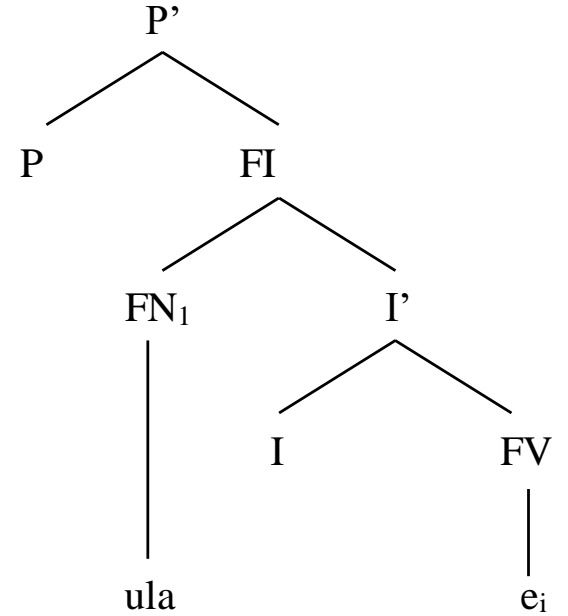

(11)
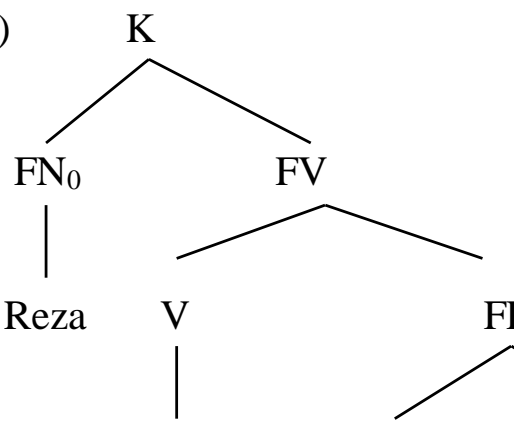

manyucuk $_{\mathrm{i}}$ Spes FP
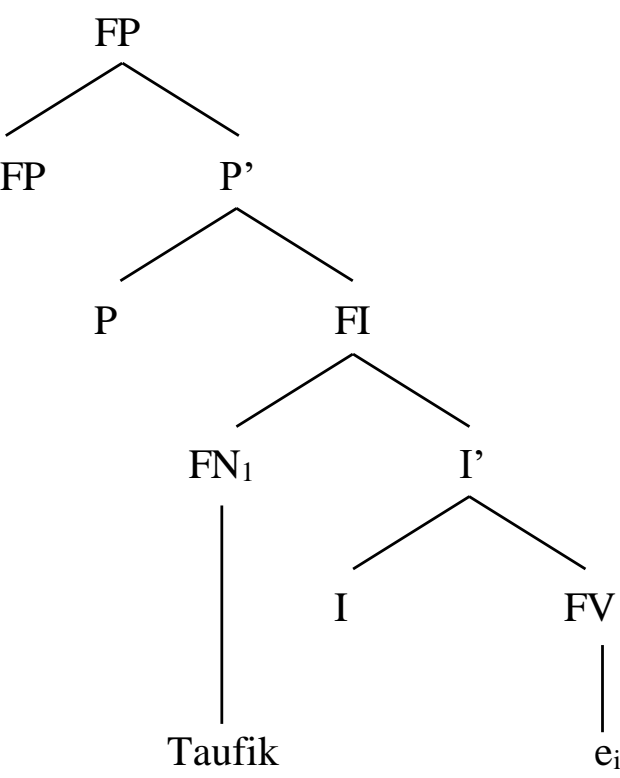
Masing-masing kalimat (8), (9), (10), (11) memilki dua kejadian. Kejadian pertama pada kalimat (8) adalah Budi manutup pintu sebagai komponen sebab yang ditampilkan secara ekplisit dan pintu menjadi dalam keadaan tertutup dapat dipahami sebagai komponen akibat walaupun komponen ini tidak ditampilkan secara eksplisit. Sama halnya seperti kejadian pertama pada kalimat (9) adalah Ambo mambukak lapo sebagai komonen sebab yang ditampilkan secara eksplisit dan kejadian kedua adalah lapo menjadi dalam keadaan terbuka dapat dipahami sebagai komponen akibat walaupun komponen ini tidak dimunculkan secara eksplisit. Kalimat (10) Angku mambunuh ula sebagai komponen sebab yang ditampilkan secara eksplisit dan kejadia kedua menyebabkan ula dalam keadaan mati. Kalimat (11) juga memiliki dua kejadian, yakni kejadian pertama adalah sebagai komponen sebab ditampilkan secara eksplisit dan komponen kedua adalah Reza manyucuk Taufik dalam keadaan tertusuk (luka) sebagai komponen akibat yang tidak dimunculkan secara eksplisit.

\section{PENUTUP}

Struktur dasar kalimat kausatif dalam bahasa Aceh Singkil dibentuk dari spesifier, infleksi, dan frasa verba. Namun, dalam struktur derivasinya verba berpindah ke posisi [SPES, FP] yang semula didominasi oleh sebuah FV di bawah FI berpindah ke posisi Spes FP dan meninggalkan jejak pada posisinya yang lama.

Penelitian ini hanya membahas struktur kalimat kausatif dalam bahasa Aceh Singkil. Oleh karena itu, perlu diteliti jenis kalimat lain yang ada dalam bahasa tersebut, khususnya menggunakan teori Xbar.

\section{DAFTAR PUSTAKA}

Comrie, B. (1981). Language Universals and Linguistic Typology. Oxford: Basil Blackwell.

Goddard, C. (1998). Semantic Analysis - A Practical Introduction. Oxford: Oxford University.

Hadi, W. (2007). Konstruksi Kausatif Bahasa Serawai. Fakultas Bahasa dan Seni Universitas Negeri Medan. Diakses pada September 19, 2017 dari http://jurnal.unimed.ac.id.

Haegemen, L. (1994). Introduction to Goverment and Binding Theory. Malden: Blackwell.

Kridalaksana, H. (2009). Kamus Linguistik. Jakarta: Gramedia.

Mayani, L A. (2005). Konstruksi kausatif bahasa Madura. Linguistik Indonesia, 23(2), 237-249.

Mulyadi. (2004). Konstruksi kausatif dalam bahasa Indonesia. Linguistika, 21(11), 133-145.

Mulyadi. (2010). Frasa preposisi bahasa Indonesia: analisis X-Bar. Kajian Sastra, 34(1), 1-12.

Payne, T E. (1997). Describing Morphosyntax: A Guide for Field Linguistics. Cambridge: Cambridge University Press.

Shibatani, M (Eds.). (1976). Syntax and Semantic: The Grammar of Causative Construction. New York: Academic Press.

Sudaryanto. (2015). Metode dan Aneka Teknik Analisis Bahasa. Yogyakarta: Sanata Dharma University Press. 
Daftar Singkatan

$\begin{array}{ll}\text { Akt } & \text { Aktif } \\ \text { Def } & \text { Definit } \\ \text { FI } & \text { Frasa Infleksi } \\ \text { FN } & \text { Frasa Nomina } \\ \text { FP } & \text { Frasa Preposisi } \\ \text { FV } & \text { Frasa Verba } \\ \text { I } & \text { Infleksi } \\ \text { K } & \text { Kalimat } \\ \text { Kaus } & \text { Kausatif }\end{array}$

$\begin{array}{ll}\mathrm{N} & \text { Nomina } \\ \mathrm{P} & \text { Preposisi } \\ \mathrm{P} 1 \mathrm{t} & \text { Persona Pertama Tunggal } \\ \text { Spes } & \text { Spesifier } \\ \text { V } & \text { Verba }\end{array}$

\section{Daftar Lambang}

i indeks unsur yang pindah

$\mathrm{e}_{\mathrm{i}} \quad$ Jejak yang ditinggalkan 